\title{
IMPLEMENTASI MOTION GRAPHIC TATA CARA UMROH PADA PT. RHEAN CITRA OETAMA
}

\author{
Adelia Khairunnisa ${ }^{1}$, Maidel Fani ${ }^{2}$ \\ * Informatics Engineering, Batam State Polytechnic \\ ** Multimedia and Network Engineering, Batam State Polytechnic
}

\begin{tabular}{l} 
Article Info \\
\hline Article history: \\
Received Jun $12^{\text {th }}, 2021$ \\
Revised Jun $20^{\text {th }}, 2021$ \\
Accepted Jul $26^{\text {th }}, 2021$ \\
\hline
\end{tabular}

\section{Keyword:}

Motion Graphics

Procedures for Umrah

Luther-sutopo

Umrah

\begin{abstract}
Pembuatan Motion Graphic pada tata cara pelaksanaa umroh ini merupakan salah satu bentuk media informasi yang dibuat mengikuti perkembangan teknologi. Perancangan motion graphic ini ditujukan untuk membantu calon jemaah umroh dengan minat baca yang kurang. Dengan penyampaian media yang menarik serta interaktif, diharapkan dapat meningkatkan minat belajar, dan memudahkan memahami tentang tata cara umroh yang benar. Perancangan aplikasi ini menggunakan metode Luther-Sutopo dengan beberapa tahap yaitu, concept, Design, Material Collecting, Assembly, Testing dan Distribution. Dalam motion graphic ini sendiri terdapat typographi, backsound, dubbing dan instrument. Hasil penelitian yang dihasilkan adalah Motion Graphic tata cara umroh pada PT. Rhean Citra Oetama yang disajikan dalam format MP4. Hasil analisis pengujian alfa dan pengujian beta dengan mendapatkan rata-rata persentasi nilai secara berurut $86 \%$ dan $89 \%$, dimana nilai persentase tersebut masuk kedalam kategori skala respon sangat setuju. Berdasarkan pengujian alfa dan beta yang telah dilakukan, video motion graphic pada PT Rhean Citra Oetama sebagai media pembelajaran dapat menyampaikan informasi tata cara umroh dan calon jemaah umroh mengerti dan paham tata cara umroh. Mempermudah calon jemaah umroh untuk memahami dan belajar serta menghafal doa-doa sebelum melaksanakan ibadah umroh.
\end{abstract}

\section{PENDAHULUAN}

Umroh sering disebut dengan haji kecil dan salah satu kegiatan ibadah bagi umat islam. Umroh menjadi alternatif. Ibadah umroh dalam pelaksanaannya tata cara yang harus dikerjakan dengan sempurna. Untuk dapat mengetahui tata cara ibadah umroh, calon jemaah akan mendapatkan pelajaran manasik haji. Bimbingan bagi calon jemaah baik melalui praktek secara langsung dengan cara membuat simulasi yang akan dilakukan dalam perjalanan ibadah umroh, atau diberikan buku pedoman sebagai panduan belajar pelaksanaan ibadah umroh.

PT. Rhean Citra Oetama adalah perusahaan yang bergerak dalam bidang jasa liburan tour, travel, dan umroh. Perusahan ini memiliki banyak permintaan dari masyarakat, dan mendapat pesanan pemakaian jasa perjalanan salah satunya jasa perjalanan ibadah umroh. PT. Rhean Citra Oetama membutuhkan suatu strategi baru dalam menyampaikan tata cara ibadah umroh, agar para calon jemaah dapat dengan jelas mengerti dan paham tata cara ibadah umroh. Saat ini jenis panduan tata cara ibadah umroh dibagi 2 versi yaitu berbentuk buku dan berbentuk video/motion graphic. Dalam prosesnya PT. Rhean Citra Oetama sudah memiliki petunjuk tata cara pelaksanaan umroh yang berbentuk buku yang seharusnya digunakan dengan cara dibaca dan calon jemaah akan mengikuti simulasi manasik haji namun hal tersebut belum mencapai target pemahaman para calon jemaah dikarenakan lemahnya minat membaca, cukup menyita waktu dan kurang efisien. Begitu pula dengan manasik haji, akan mengalami ketidak efektifan karena praktek secara langsung hanya bisa dilakukan beberapa kali dan akan cederung lupa setelahnya.

Media yang akan digunakan adalah video promosi dengan menggunakan konsep video berbasis animasi 2D dengan menggunakan teknik motion graphic. Konsep ini dipilih karena efektif, selain itu memudahkan konsumen atau masyarakat untuk memahami informasi didalamnya sehingga tujuan untuk memberi informasi mengenai tata cara ibadah umroh kepada konsumen atau masyarakat dapat tercapai dengan baik. 


\section{METODE PENELITIAN}

\subsection{Metode Penyelesaian Masalah}

Model pengembangan multimedia yang digunakan dalam penelitian ini adalah dengan menggunakan Luther-Sutopo dalam pembuatan produk motion graphic. Model pengembangan Luther-Sutopo ini memiliki 6 tahapan yaitu Concept, Design, Material Collecting, Assembly, Testing, dan Distribution. Tahap-tahap model pengembangan multimedia Luther-Sutopo ditunjuk pada gambar 1.

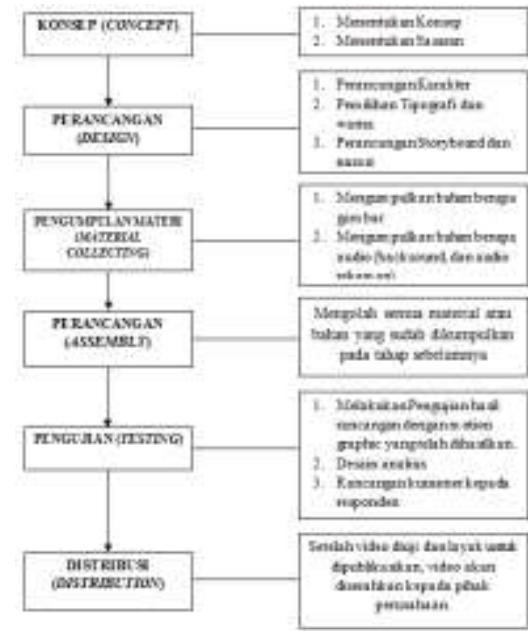

Gambar 1. Metode Luther-Sutopo

Dalam bagian metodologi hanya akan menjelaskan 3 tahapan (Consept, Design \& Material Collecting) dari 6 tahapan yang ada pada metode Luther-Sutopo, dan tahap yang lainnya akan dibahas di bagian Hasil dan Pembahasan.

\section{Concept}

Secara umum motion graphic ini menggunakan konsep 2D dengan mengangkat tema tata cara umroh. Video motion graphic di buat dengan durasi \pm 5 menit sesuai dengan kasus atau permasalahannya yaitu penyampaian informasi tentang tata cara umroh. Perancangan konsep ini dengan memperhatikan media komunikasi, pemilihan desain warna identik dengan desain karakter, , sasaran audience serta strategi publikasi bagaimana ini dapat tersampaikan pesannya ke audience.

2. Design

Pada tahap ini motion graphic tata cara umroh akan dirancang menggunakan uncur-unsur multimedia seperti karakter, tipografi, suara narasi, dan storyboard. Selanjutnya naskah dibuat berdasarkan data yang didapat dalam bentuk storyboard. Selain itu, menentukan perangkat pendukung yang akan digunakan juga sangat penting dan disesuaikan dengan storyboard yang telah dibuat.

a. Perancangan Karakter

Desain karakter akan disesuaikan dengan tema dari motion graphic ini yaitu menggunakan karakter Jemaah laki-laki, dan Jemaah perempuan. Dengan tampilan karakter yang menarik diharapkan menambah ketertarikan para audience untuk melihat motion graphic ini seperti disajikan pada Tabel 1 Karakter. 


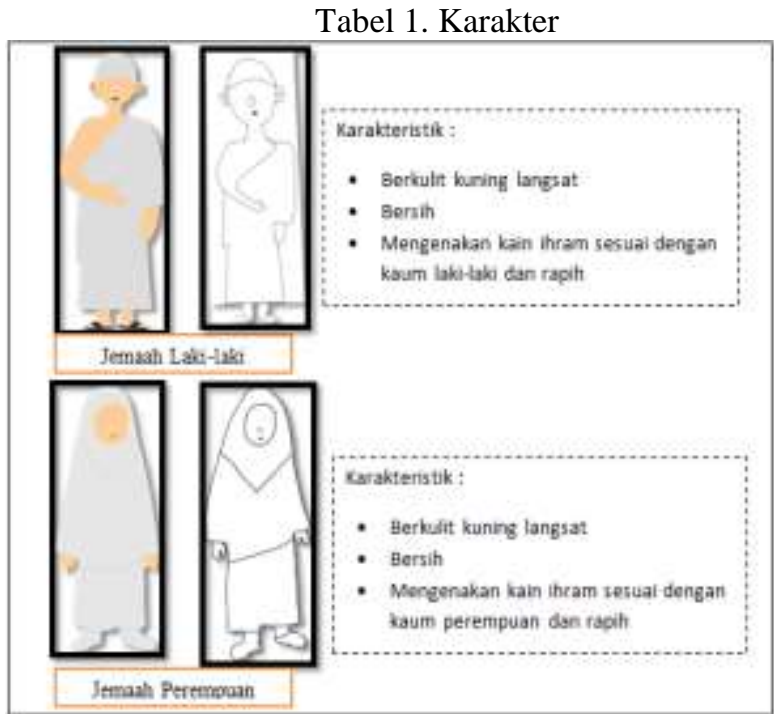

b. Tipografi

Dalam pengembangan motion grahic ini menggunakan jenis tipografi Baloo Thambi 2 ExtraBold. Jenis tipografi yang digunakan seperti disajikan pada Tabel 2 Tipografi

Tabel 2.Tipografi

\begin{tabular}{|c|c|c|}
\hline $\begin{array}{c}\text { Baloo Thambi } \\
2 \text { ExtraBold }\end{array}$ & TATA CARA UMROH & $\begin{array}{c}\text { Terlihat lebih bersih, jelas, } \\
\text { modern dan mudah dibaca }\end{array}$ \\
\hline
\end{tabular}

c. Warna

Berikut ini merupakan warna-warna yang akan digunakan pada motion graphic, yang di tunjukkan pada tabel 3 Warna.

Tabel 3. Warna

\begin{tabular}{|c|c|c|l|}
\hline No. & Warna & Kode Warna & \multicolumn{1}{|c|}{ Keterangan } \\
\hline $\mathbf{1}$ & & \#48d1cc & $\begin{array}{l}\text { Untuk menyampaikan kehandalan, } \\
\text { dapat dipercaya dan komunikasi. } \\
\text { Serta Ketenangan dan kepercayaan. }\end{array}$ \\
\hline $\mathbf{2}$ & & \multirow{\#fffff}{*}{$\begin{array}{l}\text { Menyampaikan pesan tentang } \\
\text { kesempurnaan, kesederhanaan dan } \\
\text { kemurnian.Serta bersih dan netral. }\end{array}$} \\
\hline
\end{tabular}

d. Narasi

Narasi akan membantu menyampaikan pesan yang ada didalam video. Narasi yang ada di motion graphic ini akan berupa suara yang mengiringi selama motion graphic berjalan dan berupa teks yang terletak di beberapa scene di dalam motion graphic. Narasi suara akan disesuaikan kembali dengan visual video ketika motion graphic sudah masuk ke tahapan penggabungan scene di Adobe Premiere Pro CC2017. Rincian narasi terdapat pada tabel 4 Narasi.

Tabel 4. Narasi

\begin{tabular}{|c|l|c|}
\hline Scene & \multicolumn{1}{|c|}{ Narasi Suara } & Narasi Visual \\
\hline 1 & Tata Cara Umroh & Tata Cara Umroh. \\
\hline
\end{tabular}




\begin{tabular}{|l|l|l|}
\hline 2 & $\begin{array}{l}\text { Bagian awal adalah ihram } \\
\text { yaitu niat memulai manasik } \\
\text { haji atau umroh }\end{array}$ & Ihram. \\
\hline 3 & $\begin{array}{l}\text { Pertama Sebelum berihram ada } \\
\text { beberapa hal yang harus } \\
\text { dipersiapkan, yaitu : } \\
\text { Mencukur kumis, menggunting } \\
\text { kuku, menghilangkan rambut } \\
\text { ketiak dan rambut kemaluan }\end{array}$ & $\begin{array}{l}\text { Mencukur kumis } \\
\text { Mengunting kuku } \\
\text { Menghilangkan rambut } \\
\text { ketiak dan rambut }\end{array}$ \\
\hline
\end{tabular}

e. Storyboard

Berikut ini merupakan storyboard yang akan digunakan dalam pembuatan motion graphic tata cara umroh, disajikan pada tabel 5 Storyboard

Tabel 5. Storyboard

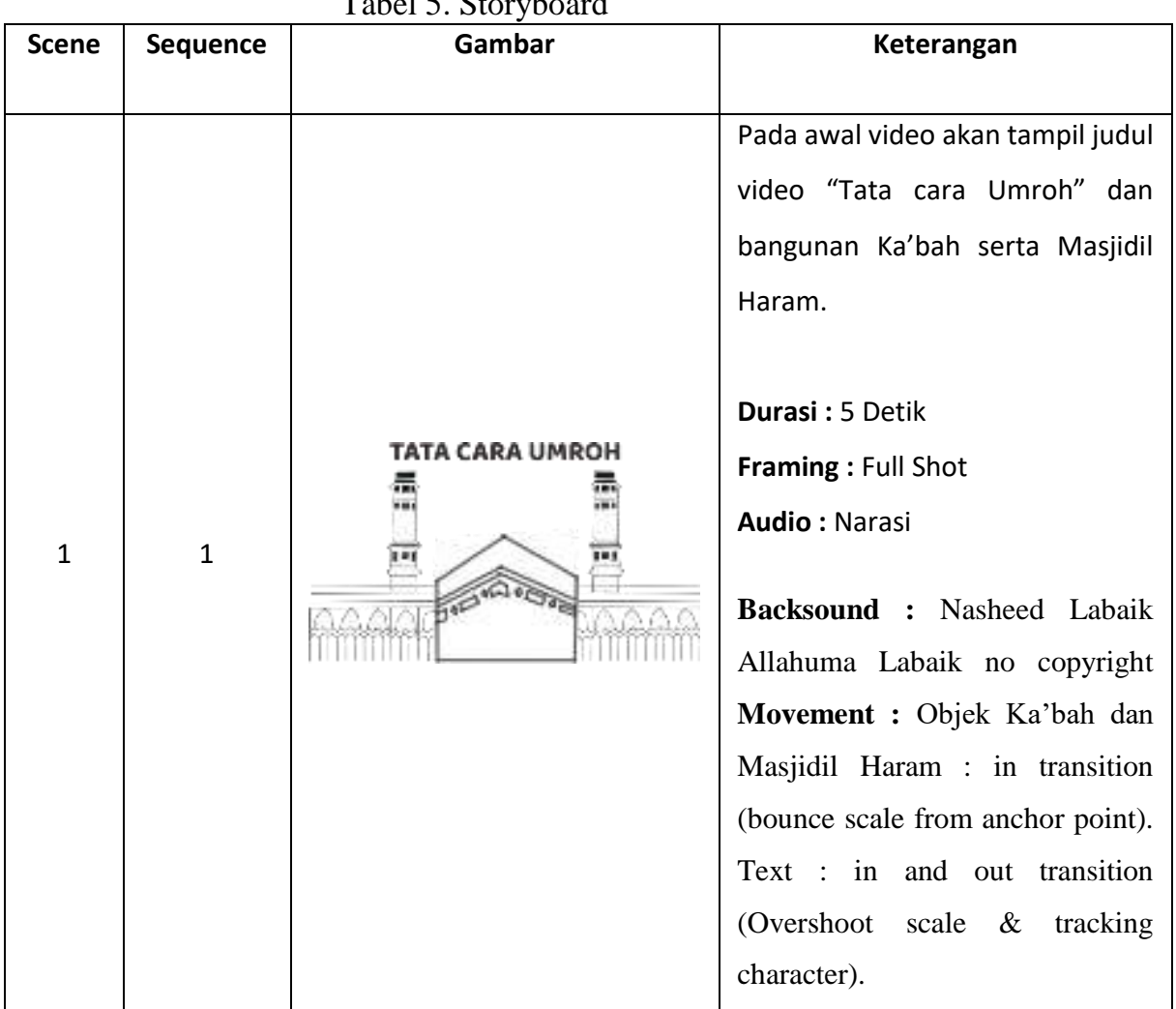




\begin{tabular}{|l|l|l|l|}
\hline & & & $\begin{array}{l}\text { Menampilkan tulisan ihram serta } \\
\text { narasi yang menerangkan } \\
\text { pengertian ihram. } \\
\text { Durasi : 6 Detik } \\
\text { Framing : Full Shot } \\
\text { Audio : Narasi } \\
\text { Backsound : Nasheed Labaik } \\
\text { Allahuma Labaik no copyright } \\
\text { Movement : Text : in and out } \\
\text { transition (Scale \& tracking } \\
\text { characters). }\end{array}$ \\
\hline
\end{tabular}

\section{Material Collecting}

Materi-materi yang diperoleh dalam tahap ini adalah gambar-gambar yang dibutuhkan dalam motion graphic yaitu properti, gambar - gambar object serta logo perusahaan.

1. Gambar

Dalam pembuatan motion graphic terdapat beberapa gambar yang dibutuhkan, seperti yang terlihat pada tabel 6 berikut gambar-gambar yang digunakan pada motion graphic ini :

\section{Tabel 6. Material Collecting}

\begin{tabular}{|c|c|c|c|c|}
\hline No. & Referensi & Gambar & Vector & Keterangan \\
\hline 1 & 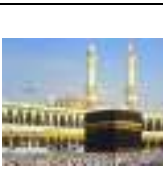 & (6) & 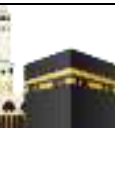 & $\begin{array}{l}\text { Ka'bah dan } \\
\text { Masjidil } \\
\text { Haram. }\end{array}$ \\
\hline 2 & & & & $\begin{array}{l}\text { Karakter } \\
\text { lelaki } \\
\text { berkumis. }\end{array}$ \\
\hline
\end{tabular}

\section{Audio}

Audio / suara narasi yang akan digunakan disesuaikan dengan informasi dan materi yang akan disampaikan. Untuk suara narasi menggunakan suara rekaman. Sedangkan untuk backsound diambil dari situs youtube.com yang non-copy right. Format audio / suara narasi yang digunakan adalah .mp3 yang nantinya akan dimasukkan ke dalam motion graphic. Dapat dilihat pada tabel 7 Audio

Tabel 7. Audio

\begin{tabular}{|l|l|l|}
\hline No. & \multicolumn{1}{|c|}{ Audio/backsound } & Keterangan \\
\hline 1. & $\begin{array}{l}\text { Nasheed Labaik Allahuma } \\
\text { Labaik no copyright }\end{array}$ & Backsound pada scene 1 sampai scene 28 \\
& & Bitrate : 96kbps \\
& & Format : Mp3 \\
& & Sumber \\
& & https://www.youtube.com/watch?v=CJpZpSJylz4 \\
& & \\
\hline
\end{tabular}




\begin{tabular}{|l|l|l|}
\hline 2 & Audio narasi scene 1 (rekaman) & Audio narasi pada scene 1 \\
& & Bitrate : 102kbs \\
& & Format : Mp3 \\
& & Sumber : rekaman \\
\hline
\end{tabular}

\subsection{Analisis \& Pengujian}

a. Analisis

Pada penelitian ini menggunakan metode analisis data kuantitatif dengan menggunakan statistik deskriptif. Menurut [6] dalam bukunya menyatakan penggunaan metode kuantitatif digunakan apabila ingin mengetahui pengaruh/treatment tertentu terhadap yang lain. Data didapat dari instrumen yang berupa kuesioner. Setelah itu kuesioner diuji dengan Alpha Testing (pengujian alfa) dan Beta Testing (pengujian beta). Pengujian alfa dilakukan pada responden yang merupakan koordinator manasik haji, karyawan PT Rhean Citra Oetama dan paham mengenai tata cara umroh. Sedangkan, pengujian beta dilakukan pada responden calon jemaah umroh yang sebelumnya tidak paham mengenai tata cara umroh.

b. Pengujian

Sampel diambil secara acak dengan teknik simple random sampling. Menurut [7] penelitian yang menggunakan analisis data statistik, ukuran sampel paling minimum adalah 30. Pengujian alfa mengambil sampel 1 orang koordinator manasik haji dan 4 orang karyawan PT Rhean Citra Oetama yang terdiri dari 1 orang direktur, 2 orang manager, dan 1 orang tour leader. Sedangkan untuk pengujian beta mengambil sampel 30 orang calon jemaah umroh. Dengan demikian total dari keseluruhan sampel adalah 35 orang.

Kuisioner yang berbentuk skala likert merupakan instrumen yang akan digunakan pada penelitian ini. Menurut [8] kemudahan yang ada pada penyusunan skala likert harus diperhatikan dengan hati-hati agar analisis lanjutan terhadap butir-butir respon tepat. Kuesioner dibedakan menjadi pengujian alfa dan pengujian beta. Pada kuesioner terdapat 5 skala respon yaitu sangat setuju (SS), setuju (S), ragu-ragu (RG), tidak setuju (TS) dan sangat tidak setuju (STS). Setiap skala respon memiliki skor yang berbeda-beda yaitu secara berurutan bernilai 5 sampai 1. Lalu, berdasarkan skor tersebut dilakukanlah perhitungan sesuai dengan rumus skala likert, yaitu:

$$
\text { Index } \%=\frac{\text { Total Skor }}{Y \times 100}
$$

Berikut adalah persentase nilai yang dapat dilihat pada Tabel 8 .

Tabel 8. TABEL PERSENTASE NILAI

\begin{tabular}{|c|c|}
\hline Nilai & Keterangan \\
\hline $80 \%-100 \%$ & Sangat Setuju \\
\hline $60 \%-79,99 \%$ & Setuju \\
\hline $40 \%-59,99 \%$ & Ragu-ragu \\
\hline $20 \%-39,99 \%$ & Tidak Setuju \\
\hline $0 \%-19,99 \%$ & Sangat Tidak Setuju \\
\hline
\end{tabular}

\section{HASIL DAN PEMBAHASAN}

4. Assembly

Pada tahap ini adalah membuat dan mengedit bahan atau material yang sudah diperoleh pada tahap sebelumnya (Material Collecting).

a. Pembuatan Motion Graphic

Pembuatan motion graphic ini menggunakan beberapa software seperti Corel Draw X8 untuk membuat background, kemudian After Effect CC 2015 untuk mengolah transisi, menyisipkan materi dan gambar-gambar menjadi sebuah motion graphic, dan 
yang terakhir Adobe Premiere digunakan untuk melakukan editing . Konten-konten ini dibuat menyesuaikan dengan storyboard yang ada.

\section{b. Render dan Editing}

Pada tahap terakhir ini yang dilakukan adalah merender hasil motion graphic yang telah dibuat menggunakan software Adobe After Effect CC2015 dengan format mp4, dan melakukan editing untuk menyesuaikan dengan hasil dubbing yang dibuat, untuk melakukan tahap editing ini dilakukan dengan menggunakan software Adobe Premiere CC2017, untuk melihat proses editing ini terlihat seperti pada gambar 8 .

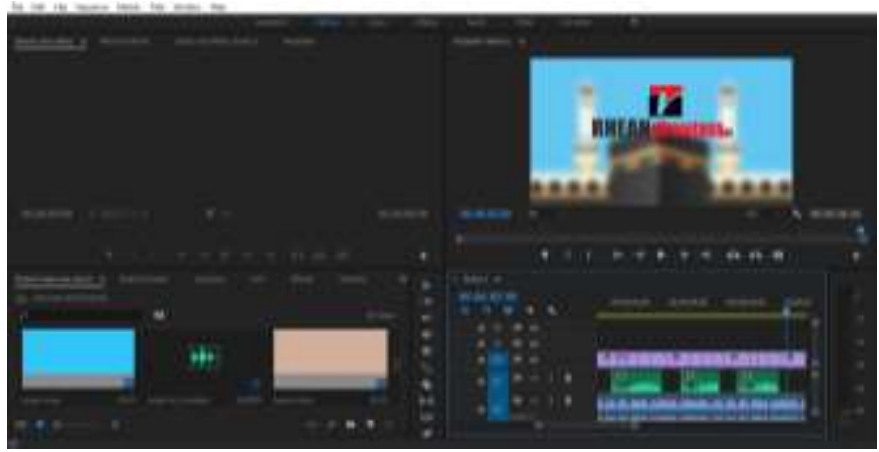

Gambar 2 Proses Editing

\section{Testing}

Setelah proses pembuatan video, maka dilanjutkan dengan proses pengujian yang dilakukan dengan penyebaran kuesioner secara online melalui google form. Pengujian tersebut dibagi menjadi alfa testing dan beta testing. Pengujian alfa dilakukan kepada 5 orang responden yang merupakan koordinator manasik haji, karyawan PT Rhean Citra Oetama yaitu 1 orang direktur, 2 orang manager, dan 1 orang tour leader. Sedangkan pengujian beta dilakukan kepada 30 orang responden calon jemaah umroh yang sebelumnya tidak paham mengenai tata cara umroh. Berikut adalah hasil pengisian kuesioner pengujian alfa dalam Tabel 9.

Tabel 9. Tabel Hasil Pengisian Kuesioner Pengujian Alfa

\begin{tabular}{|c|l|}
\hline \multicolumn{2}{|c|}{ Hasil Pengisian Kuesioner Pengujian Alfa } \\
\hline NO & \multicolumn{1}{|c|}{ Aspek } \\
\hline 1 & Penyampaian informasi tentang Ihram tersampaikan dengan jelas. \\
\hline 2 & Penyampaian informasi tentang Thawaf tersampaikan dengan jelas. \\
\hline 3 & Penyampaian informasi tentang Sai tersampaikan dengan jelas. \\
\hline 4 & Penyampaian informasi tentang Tahalul tersampaikan dengan jelas. \\
\hline 5 & Narasi dalam video dapat didengar dengan jelas. \\
\hline 6 & Suara dalam bacaan doa dapat didengar dengan jelas. \\
\hline 7 & Tata letak dan perpindahan huruf pada motion graphic ini terlihat jelas. \\
\hline 8 & Karakter dalam motion graphic ini sudah mencerminkan seorang jemaah umroh. \\
\hline 9 & Pada menit ke 01:54, cara karakter menuju ke Hajar Aswad tersampaikan dengan jelas. \\
\hline
\end{tabular}


Pada menit ke 03:14, cara karakter menuju ke bukit shafa untuk melakukan Sai tersampaikan dengan jelas.

Berdasarkan dari aspek pertanyaan di atas, hasil pengisian kuesioner pengujian alfa dapat dilihat pada gambar 3 .

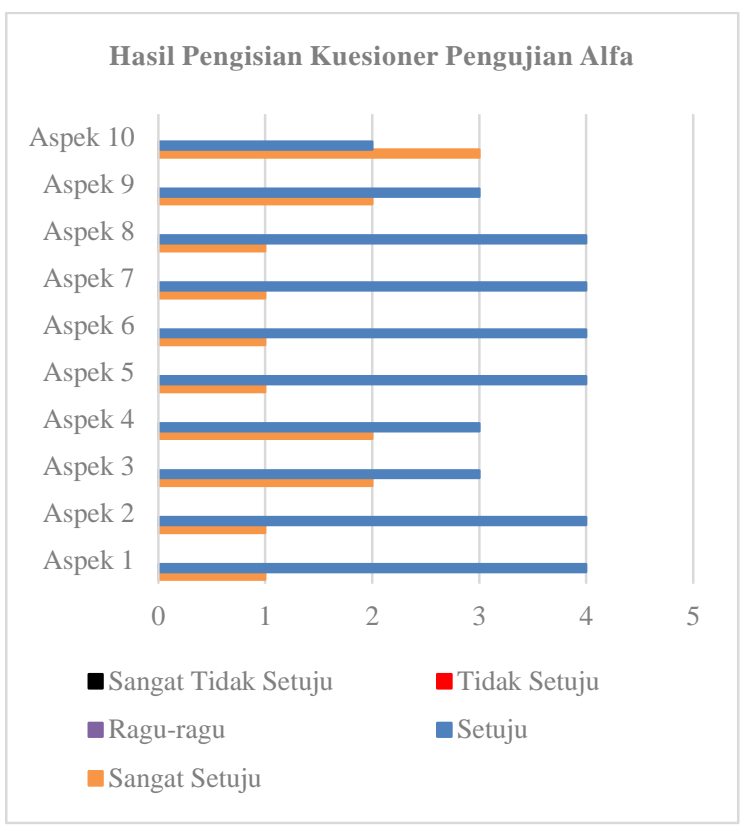

Gambar 3 Grafik pengisian kuesioner pengujian alfa oleh 5 orang responden.

Dari hasil grafik pengisian kuesioner pengujian alfa di atas dapat dilihat bahwa responden pengujian alfa rata-rata memilih skala respon sangat setuju dan setuju. Setelah itu hasil dari pengisian kuesioner dihitung dengan rumus skala likert yang akan menghasilkan persentase nilai dari pengujian alfa. Berikut adalah perhitungan skala likert dari pengujian alfa dalam gambar 4.

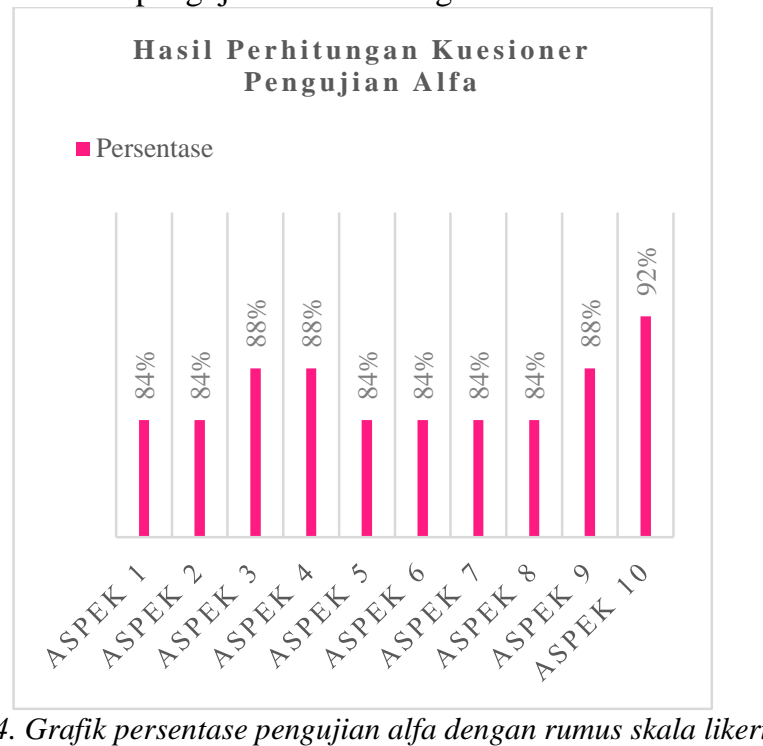

Berdasarkan dari grafik di atas, persentase paling tinggi diperoleh dari aspek pertanyaan nomor 10 yang berjumlah $92 \%$ dan persentase paling rendah diperoleh dari aspek pertanyaan nomor 1, 2, 5, 6, 7 dan 8 yaitu $84 \%$. Rata-rata persentase nilai pengujian alfa mendapatkan hasil $86 \%$ yang masuk dalam kategori sangat setuju. Berdasarkan perolehan persentase tertinggi dan terendah pada pengujian alfa bahwa implementasi motion graphic tata cara umroh sangat berpengaruh dalam menyampaikan informasi mengenai tata cara umroh dan informasi tersampaikan dengan jelas. Setelah melakukan pengujian alfa, 
selanjutnya adalah pengujian beta kepada 30 responden umum. Berikut adalah aspek pertanyaan dari kuesioner pengujian beta dalam Tabel III.

Tabel 10. Tabel Hasil Pengisian Kuesioner Pengujian BETA

\begin{tabular}{|c|c|}
\hline \multicolumn{2}{|r|}{ Hasil Pengisian Kuesioner Pengujian Beta } \\
\hline NO & Aspek \\
\hline 1 & Penyampaian informasi tentang tata cara umroh dapat dipahami. \\
\hline 2 & Narasi dalam video didengar dengan jelas. \\
\hline 3 & Suara dalam bacaan doa dapat didengar dengan jelas. \\
\hline 4 & Waktu perpindahan atau transisi scene ke scene sudah baik. \\
\hline 5 & Karakter dalam motion graphic ini sudah mencerminkan seorang jemaah umroh. \\
\hline 6 & $\begin{array}{l}\text { Pada menit ke 01:54, karakter menuju ke Hajar Aswad dan caranya Ke Hajar Aswad tersampaikan } \\
\text { dengan jelas. }\end{array}$ \\
\hline 7 & $\begin{array}{l}\text { Pada menit ke 03:14, cara karakter menuju ke bukit shafa untuk melakukan Sai tersampaikan } \\
\text { dengan jelas. }\end{array}$ \\
\hline 8 & $\begin{array}{l}\text { Video pembelajaran ini merupakan video yang tampil beda dalam pemaparan informasi, sehingga } \\
\text { mudah di ingat. }\end{array}$ \\
\hline 9 & $\begin{array}{l}\text { Gambar/tampilan pada video tata cara umroh menggunakan symbol dan warna yang jelas mampu } \\
\text { menyampaikan isi pesan dari gambar tersebut. }\end{array}$ \\
\hline 10 & $\begin{array}{l}\text { Video pembelajaran ini mampu memberikan pengetahuan kepada calon jemaah tentang tata cara } \\
\text { umroh. }\end{array}$ \\
\hline
\end{tabular}

Berdasarkan dari aspek pertanyaan di atas, hasil pengisian kuesioner pengujian beta dapat dilihat pada gambar 5.

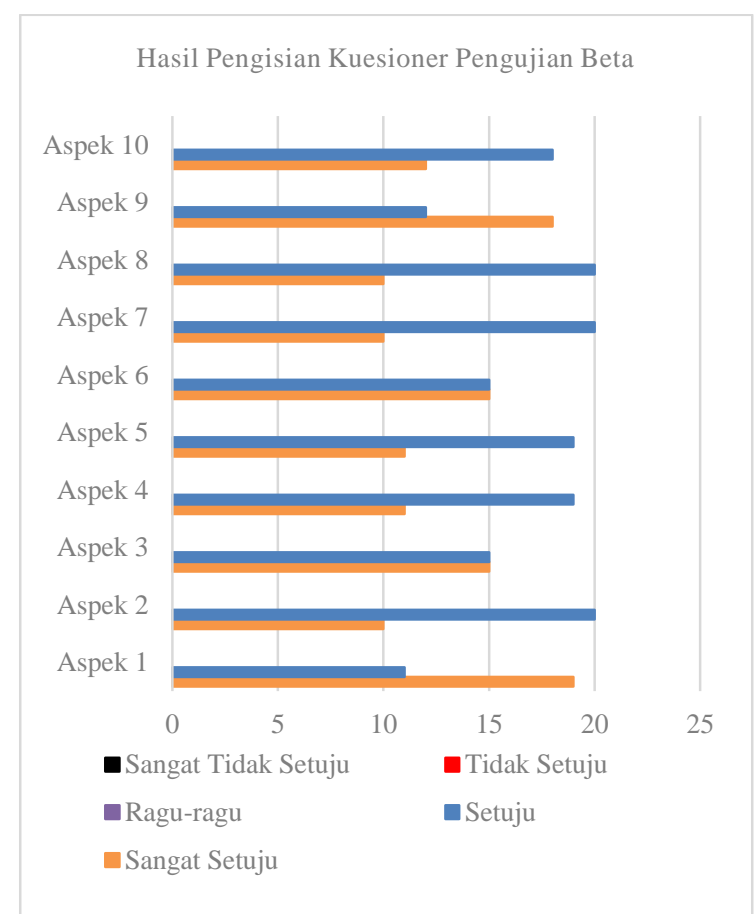

Gambar 5 Grafik pengisian kuesioner pengujian beta oleh 30 orang responden. 
Dari hasil grafik pengisian kuesioner pengujian beta di atas dapat dilihat bahwa responden pengujian beta rata-rata memilih skala respon sangat setuju, dan setuju. Lalu pengisian kuesioner beta dihitung dengan rumus skala likert. Berikut adalah hasil persentase perhitungan skala likert pengujian beta dalam gambar 6 .

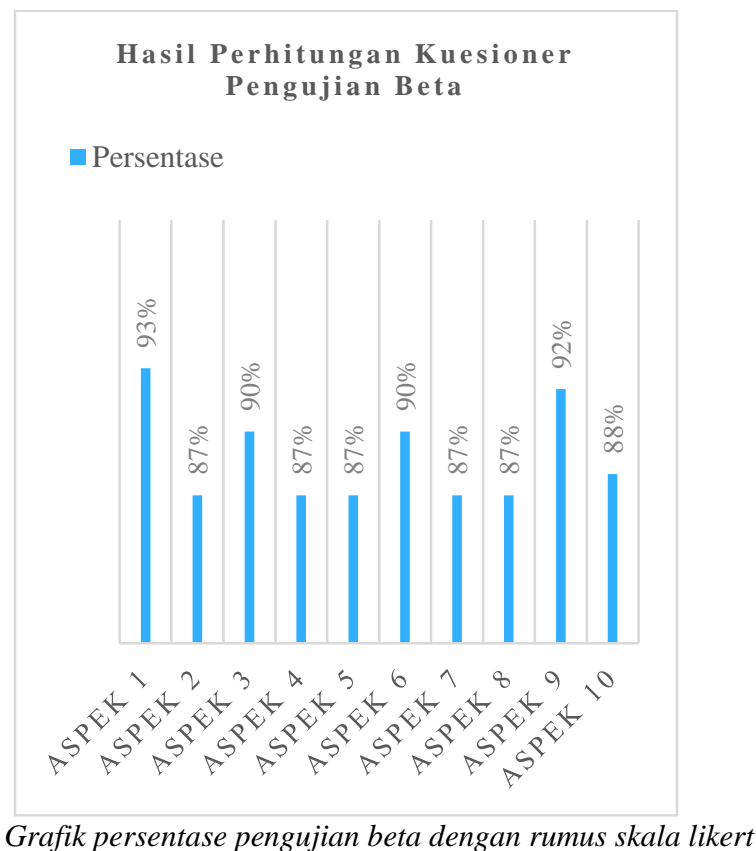

Berdasarkan dari grafik di atas, persentase paling tinggi diperoleh dari aspek pertanyaan nomor 1 yang berjumlah $93 \%$ dan persentase paling rendah diperoleh dari aspek pertanyaan nomor 2, 4, 5, 7, dan 8 yaitu $87 \%$. Berdasarkan perolehan persentase tertinggi pada pengujian beta bahwa informasi umum tata cara umroh tersampaikan dengan jelas.

Berdasarkan rata-rata persentase nilai pengujian beta mendapatkan hasil $89 \%$ dan masuk dalam kategori sangat setuju. Jadi dapat disimpulkan dari kedua pengujian diatas bahwa implementasi motion graphic tata cara umroh pada PT Rhean Citra Oetama bisa menyampaikan informasi mengenai tata cara umroh dengan jelas.

6. Distribution

Setelah video diuji dan layak untuk dipublikasikan, video akan diserahkan kepada pihak PT Rhean

Citra Oetama sebagai aset perusahaan.

\section{KESIMPULAN}

Berdasarkan pengujian dan analisis yang telah dilakukan maka didapata kesimpulan :

1. video motion graphic tata cara umroh pada PT Rhean Citra Oetama yang dikemas dalam format .mp4 berdurasi 5 menit 05 detik merupakan video pembelajaran tata cara umroh yang menyajikan mengenai apa saja tata cara umroh dari awal ihram sampai tahallul.

2. Setelah itu, berdasarkan hasil dari analisis pengujian alfa dan pengujian beta, dengan mendapatkan rata-rata persentasi nilai secara berurut $86 \%$ dan $89 \%$, dimana nilai persentase tersebut masuk kedalam kategori skala respon sangat setuju. Hal tersebut menunjukkan bahwa video tata cara umroh pada PT Rhean Citra Oetama bisa menyampaikan informasi mengenai tata cara umroh dengan mengimplementasikan teknik motion graphic.

3. Lalu, berdasarkan pengujian alfa dan beta yang telah dilakukan, video motion graphic pada PT Rhean Citra Oetama sebagai media pembelajaran dapat menyampaikan informasi tata cara umroh dan calon jemaah umroh mengerti dan paham tata cara umroh. Mempermudah calon jemaah umroh untuk memahami dan belajar serta menghafal doa-doa sebelum melaksanakan ibadah umroh.Serta calon jemaah umroh juga tidak harus membawa buku pedoman melainkan hanya dengan membuka video motion graphic tata cara umroh didalam smartphone masing-masing. 


\section{REFERENSI}

[1] Kementerian Agama RI. Buku Tuntunan Manasik Haji Dan Umrah. Jakarta. Direktorat Jenderal Penyelenggaraan Haji dan Umrah, 2016.

[2] Asy-Syafi'I, Abu.M.A. Buku Tuntunan Manasik Haji Dan Umrah. Jakarta. Pustaka Ibnu Umar, 2016.

[3] Gusman, N,.M., dkk., 2018.Pembuatan Motion Graphic Untuk Memperkenalkan Perpustakaan Kepada Siswa Sekolah dasar dalam bentuk video.

[4] Anggraini, Y., dkk., Analisis Dan Implementasi Motion GraphicIklan Layanan Masyarakat Dengan Metode Semiotika Peirce, (2017).

[5] Yunus, A.S.A., 2016, Multimedia Interaktif Sebagai Media Pembelajaran Manasik Haji Menggunakan Model Simulasi Dan Tutorial, Website : https://repository.polibatam.ac.id/view?id=2499.

[6] Sugiyono, Metode penelitian pendidikan:(pendekatan kuantitatif, kualitatif dan $R \& D$ ), Kedua. Bandung: Alfabeta, 2019.

[7] D. H. Mahmud and M. Si, "Metode Penelitian Pendidikan, Bandung: CV," Pustaka Setia, 2011.

[8] W. Budiaji, "Skala Pengukuran dan Jumlah Respon Skala Likert (The Measurement Scale and The Number of Responses in Likert Scale)," Ilmu Pertan. dan Perikan., vol. 2, no. 2, pp. 127-133, 2013.

[9] J. Leirpoll, D. Osborn, P. Murphy, and A. Edwards, The Cool Stuff in Premiere Pro: Learn advanced editing techniques to dramatically speed up your workflow. 2017.

[10] T. T. Le, A. Almansa, Y. Gousseau, and S. Masnou, "Object removal from complex videos using a few annotations," Comput. Vis. Media, vol. 5, no. 3, pp. 267-291, 2019, https://link.springer.com/article/ 10.1007/s41095-019-0145-0. 